\title{
Existing methods of dehydration of sapropel
}

\author{
Tatiana Utenkova ${ }^{1}$, Eldar Kremcheev ${ }^{1}$, and Olga Korotkova ${ }^{1}$ \\ ${ }^{1}$ Saint-Petersburg Mining University, Department of mechanical engineering, 21st Line V.O., 2, \\ 199106, Saint-Petersburg, Russia
}

\begin{abstract}
The Russian Federation has large reserves of lake sapropel. In Russia, there are about 50 thousand deposits of sapropel of natural humidity. Sapropel is used in various fields: medicine, construction, animal husbandry and agriculture. So, extracting sapropel, we get not only environmentally friendly raw materials, but also clean lakes that are sources of fresh water and recreational activity. In order to use sapropel, it is necessary to lower its moisture. Difficulties associated with dehydration of sapropel arise due to the high natural humidity of sapropel, which reaches $98 \%$, as well as due to the fact that sapropel has a fine colloidal structure. This article presents the analysis of existing methods and engineering solutions for sapropel dewatering.
\end{abstract}

\section{Introduction}

Sapropel has long been as a fertilizer. But in Russia, research of sapropels started only in the early 19th century with the creation of the Sapropel Committee of the Russian Academy of Sciences. On the territory of the Russian Federation the detected reserves of sapropel amount to about 225 billion $\mathrm{m} 3$ of natural humidity. The largest sapropel mining and processing enterprises in Russia are shown in Table 1.

Sapropel is used in agriculture, medicine, construction, and in the fuel industry. Sapropel fertilizers have proven their effectiveness and have a number of advantages over other fertilizers. The sapropel based fertilizer is the only soil-forming fertilizer of its kind. It can be used for all types of soils in order to restore their fertility and structure. The longterm effect of sapropel is based on the high resistance to washing out during irrigation, rain or influence of ground water.

The influence of lime sapropel on soil fertility was studied at the Lithuanian agricultural institute. The overall result of long-term experiments (about 18 years) was positive. There was an improvement in chemical properties: the content of useful components increased, soil acidity decreased, and the yield of grain crops increased [1].

In construction, a method of using sapropel as a binding composition for the production of fuel briquettes is known and described in [2]. According to that source, Sapropel dries out at $110{ }^{\circ} \mathrm{C}$, then it is subjected to mechanical activation. The use of sapropel as a binder improves the technical performance of coal briquettes and makes the briquetting process more efficient.

Sapropel can be used as a binder for the production of pellets from coal ash, which can be used in agriculture and forestry as a fertilizer. [3]. 
Activated sapropel is added to the asphalt concrete mix during the construction of highways, airfields and bridges, which is described in [4]. The strength of such asphalt concrete is approximately 1.5-3 times higher than other known asphalt concrete mixtures [5].

So far, the cheapest and most technologically advanced method of exploration sapropel deposits is the hydro-mechanized method, in which sapropel is extracted using a dredger. Transportation of watery sapropel to the shore sedimentation tanks is carried out using pressure or, in rare cases, gravity slurry pipelines [6].

Currently, the main issue with sapropel processing is its high humidity. Humidity of organic sapropels reaches $92-96 \%$ and sapropel is practically not filtered [7]. The choice of dewatering method depends on the composition and properties of sapropel, on the type of products to be produced.

Table 1. The largest sapropel mining and processing enterprises in Russia.

\begin{tabular}{|c|c|c|c|c|}
\hline $\begin{array}{l}\text { Plant for the } \\
\text { extraction of } \\
\text { sapropel }\end{array}$ & Deposit & $\begin{array}{c}\text { Sapropel } \\
\text { mining and } \\
\text { processing } \\
\text { technique }\end{array}$ & Product & $\begin{array}{l}\text { Production } \\
\text { capacity }\end{array}$ \\
\hline $\begin{array}{l}\text { LLC «Ekovit» } \\
\text { "Ekobit" }\end{array}$ & $\begin{array}{l}\text { Lake Savelevo, } \\
\text { Pereslavsky } \\
\text { district, } \\
\text { Yaroslavl region }\end{array}$ & $\begin{array}{l}\text { Dredging; } \\
\text { Mixing with } \\
\text { dried ( } 27 \% \\
\text { humidity) peat }\end{array}$ & $\begin{array}{l}\text { Organic, soil-forming } \\
\text { fertilizer }\end{array}$ & $\begin{array}{l}10,000- \\
20,000 \mathrm{t} / \text { year }\end{array}$ \\
\hline $\begin{array}{c}\text { LLC } \\
\text { «AGROCENTER» }\end{array}$ & $\begin{array}{l}\text { Lakes of the } \\
\text { Chelyabinsk } \\
\text { region }\end{array}$ & $\begin{array}{l}\text { Freezing in } \\
\text { sedimentation } \\
\text { tank }\end{array}$ & $\begin{array}{l}\text { Organic fertilizers, } \\
\text { soil mixtures, soils }\end{array}$ & $2000 \mathrm{~m}^{3} /$ year \\
\hline $\begin{array}{c}\text { LLC } \\
\text { «Geospetsstroy» }\end{array}$ & $\begin{array}{l}\text { Lake Cavalerul, } \\
\text { Tyumen oblast }\end{array}$ & $\begin{array}{l}\text { Dredging; } \\
\text { dewatering in } \\
\text { geotubes, }(89- \\
94 \% \text { to } 60 \%)\end{array}$ & $\begin{array}{l}\text { Loose sapropel, pasty } \\
\text { sapropel, tableted } \\
\text { sapropel, combined } \\
\text { organic-mineral } \\
\text { mixture } \\
\end{array}$ & $120000 \mathrm{t} /$ year \\
\hline $\begin{array}{l}\text { LLC «RUSEKO } \\
\text { ORGANICS» }\end{array}$ & $\begin{array}{l}\text { Lakes of the } \\
\text { Chuvash } \\
\text { Republic }\end{array}$ & $\begin{array}{l}\text { Dredging; } \\
\text { dewatering in } \\
\text { geotubes }\end{array}$ & $\begin{array}{l}\text { Tableted sapropel, } \\
\text { feed for birds and } \\
\text { animals, } \\
\text { organomineral } \\
\text { fertilizer }\end{array}$ & $\begin{array}{l}\text { (to be } \\
\text { commissioned } \\
\text { in } 2020 \text {.) }\end{array}$ \\
\hline LLC «Ecovector» & $\begin{array}{l}\text { the White lake, } \\
\text { Novosibirsk } \\
\text { oblast }\end{array}$ & $\begin{array}{l}\text { Dredging; } \\
\text { Sedimentation; } \\
\text { Granulation }\end{array}$ & Feed additive & $10000 \mathrm{t} /$ year \\
\hline
\end{tabular}

\section{Materials and methods}

At the moment, a whole range of methods for sapropel dewatering has been developed and introduced into production, among which the most common are centrifugation and filtration.

Precipitation centrifuges are not suitable for dewatering of colloidal sapropel. Devices of this type are characterized by complexity and low reliability of the design, so for dewatering of sapropels, filter centrifuges are the most commonly-used.

Dewatering in a centrifuge [8] (Fig.1) occurs under the effect of centrifugal forces that occur when the conical rotor rotates around its axis and around the precession axis, which is at an angle to the rotor axis. The sapropel passes through the filter element, which is located on the inner surface of the conical rotor. The separated moisture flows down the walls of the case and flows out of the device, the dehydrated sapropel moves along the surface of the rotor to the discharge window [8]. 

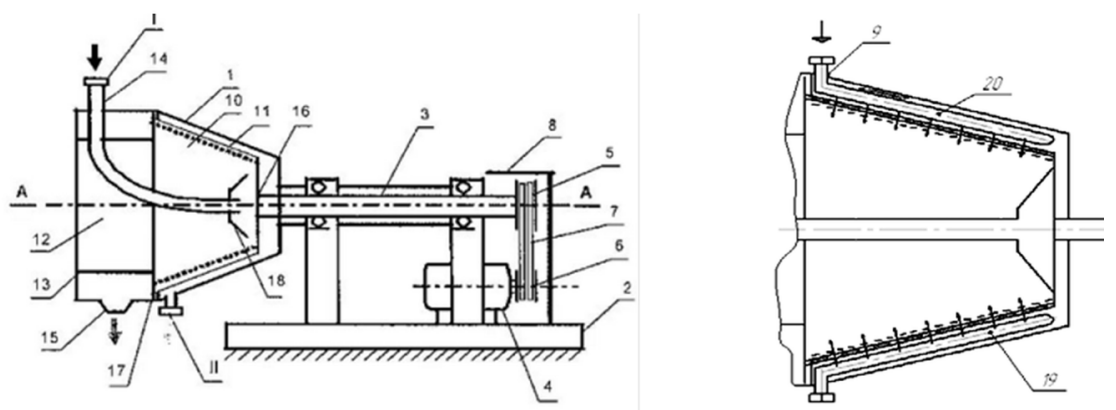

Fig. 1. Centrifuge [8] 1 - apparatus casing; 2 - fabricated frame; 3 - transmission shaft; 4 - electric motor; 5, 6 - pulleys; 7 - belt; 8 - casing; 9 - pipes for supplying hot air; 10 - perforated rotor; 11 filter element; 12 - top cover; 13 - clamp; 14 - pipe for supplying the slurry (sapropel); 15 - window for unloading the solid material; 16 - hub; 17 - flange; 18 - glass for evenly distributing the flow along the moving line of rotor; 19 - nozzles for cleaning the filter element from solid particles.

In filter centrifuge (Fig. 2), sapropel pulp is fed into the inner cavity of the upper part of the cylindrical rotor. When the rotor and the screw shaft rotate in the same direction, but at different angular speed, sapropel pulp, falling on the screw blades, is thrown by centrifugal forces on the inner surface of the cylindrical part of the rotor. The sapropel mass moves to the lower cylindrical part of the rotor due to the pressure created by the auger blade, and is removed from the device. The water contained in the pulp passes through the filter elements and is ejected outside the rotor into the casing through the holes, then removed from the centrifuge. The dewaterability of sapropel in filter centrifuges is about $85 \%$.

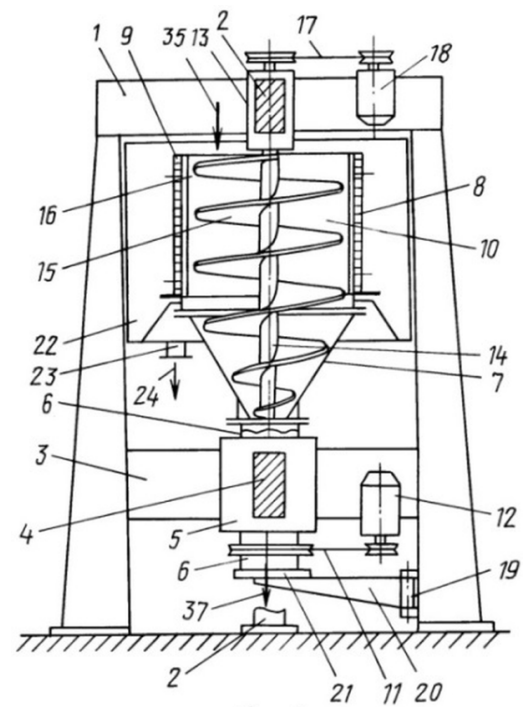

Fig. 2. Filter centrifuge for sapropel dewatering 1,2 - racks; 3,4 - crossbars; 5 - bearing assembly, 6,7,8 - lower, middle, upper parts of the rotor; 9 - holes; 10 - filter block; 11 - belt transmission; 12 - engine; 13 - bearing assembly; 14 - vertically oriented shaft; 15 - screw blades; 16 - gap; 17 - belt transmission; 18 - engine; 19 - hinge assembly; 20 - wall bracket; 21 - valve; 22 - casing; 23 branch pipe; 24 - Fugate outlet; 35- dampers; 37-unloading of dehydrated sapropel.

In machines for dewatering sapropel [4] and complexes for reducing the moisture content of sapropel [7] dewatering occurs due to the hygroscopic effect of a porous material 
of an unlocked capillary structure. All these technological devices include loading and unloading devices, a flexible belt closed on the drive drum and tension drum, over which water separators are installed in series. In this case, the water separator is a drum covered with a layer of porous material. In devices of this type, up to $85 \%$ of the moisture from the initial pulp mass is removed, and the final water content of sapropel is $74-91 \%$.

The principle of operation can be considered on the example of a complex for reducing the moisture content of sapropel [7] (figure 3).

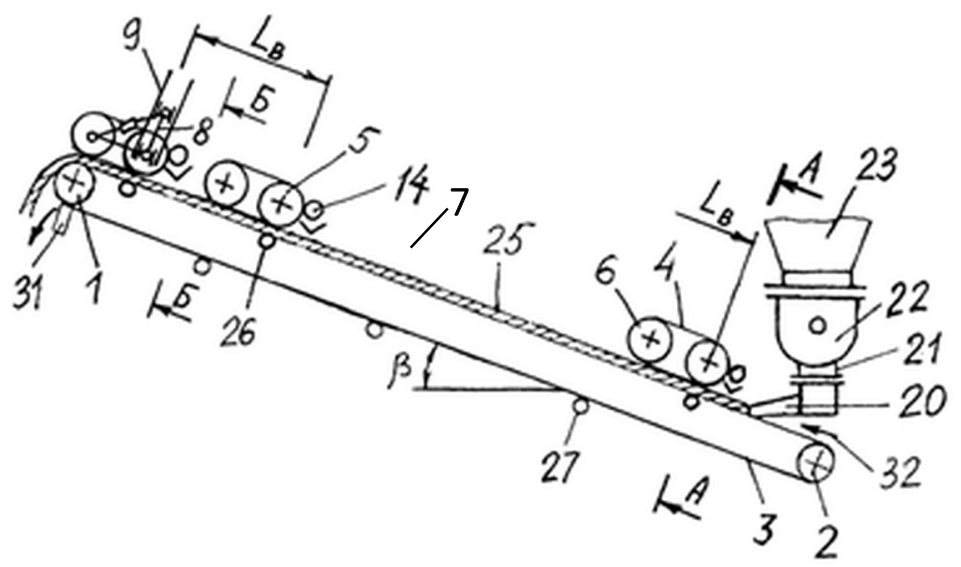

Fig. 3. Complex for reducing the moisture content of sapropel [7] 1,2 - drive and tension drums; 3 flexible belt; 4 - flexible belt of water separators; 5, 6 - drums; 7 - a layer of porous material; 8 - the first link of three-link mechanism; 9 - guide; 10 - second link of three-link mechanism (connects the axis of the drums 5 and 6); 11 - third link; 12 - screw coupling; 13 - chain gear; 14 - wringer roll; 20 - slit doser; 21 - branch discharge pipe; 22 - screw; 23 - mixing tank; 25 - a layer of sapropel; 26, 27 - roller bearing; 31 - scraper cleaner; 32 - the direction of movement of the upper branch of the flexible belt.

A thin layer of sapropel is fed to the upper branch of the flexible belt. Moving with the belt, the sapropel interacts with the water separator, which has the form of a belt covered with a porous material of an unlocked capillary structure. Dewatering occurs due to the gyroscopic effect when the porous material is cyclically compressed and restored. The dehydrated sapropel is dumped from the belt into the receiving device and transferred to further processing or drying. The watered layer of porous material runs on the wringer roller, water enters the inclined chute, and then into the drain pipe. Devices [4] differ from the described mechanized complex in the presence of an air feeder (air heated to $50-60^{\circ}$ from the into the apparatus casing), the angle of the flexible belt, the ability to adjust the pressure of the water separator on the flexible belt with a thin layer of sapropel, etc.

There is a technology for dehydration watered suspensions (silts) in Geotube geotextile containers, which is widely used in Europe and the United States. Geotube containers are manufactured by the Dutch company TenCate, which has extensive experience in manufacturing fabrics for industrial purposes, the Indian company KK Enviro and the Chinese company Geotrst, which produce geotubes from natural fibers, and others companies. The essence of the technology is to fill the container with pulp and wait for the free water to run off. After the free water drains, it is pumped up again (from 1 to 5 times). For dewatering fine slurry it is necessary to add flocculants, which improves the effect. The 
volume reduction reaches $90 \%$, and the final water content of suspensions (silts) is about 66 $\%$.

There is an invention related to agriculture, which includes a container (geotube) made of a strong filter material, made in the form of a sleeve and a device for feeding sapropel. After filling the container with sapropel of natural moisture content, it should be frozen and thawed under natural conditions in a certain temperature range, then dried in a chamber drier to $60 \%$ moisture content. It is known that preliminary freezing improves the process of removing water. After freezing, the sapropel becomes loose and easily filtered [19].

In Russia, there is a technology for producing a soil-forming fertilizer based on peat and sapropel, which uses sapropel of natural moisture content. The advantage of this technology is the absence of long-term drying of sapropel, but dewatering of peat is an energyconsuming and long-term process.

The choice of the structure of the complex for preliminary dewatering depends on the type of products produced and the water-physical properties of sapropel.

\section{Results and discussion}

In the Russian Federation a limited number industrial facilities are engaged in the extraction and processing of sapropel despite on the large number of deposits of this unique environmentally friendly natural raw material. It means that in our country the production of highly liquid products based on sapropel does not receive due attention.

The conducted research of technologies for sapropel dewatering has shown that devices for sapropel dewatering are far from perfect. Existing technologies and devices $[8,9,10$, $11,12]$ are based on the use of filtration mechanism, while it is known that sapropel is practically not filtered. Therefore, high efficiency of sapropel extraction processes is not technically provided.

Often sapropel plants use inefficient drying technology, the process of which takes a long time (the entire summer season). In addition to the fact that significant areas are allocated for drying sapropel, during prolonged drying, sapropel gets polluted by plant seeds, which leads to a decrease in the commodity properties quality of the finished product.

\section{Conclusions}

The basis for creating equipment for sapropel dewatering can be a complex for dewatering sapropel [7], machines for dewatering sapropel [4] and a machine for reducing the moisture content of sapropel, because in this type of apparatus dehydration occurs due to the hygroscopic effect of a porous material of unlocked capillary structure.

The purpose of the further research is to design the sapropel dewatering machine using new technical principles and to determine:

- the parameters and operating modes of the equipment for sapropel dewatering;

- the thickness of the layer of porous material of the unlocked capillary structure;

- the pressure of the water separator on the flexible belt with the sapropel layer;

- the number of compression cycles, stages.

Also check the need for additional energy (heat) supply.

\section{References}

1. E. Baksiene, V. Janusiene, Plant, Soil and Environment, 12, 539-544 (2006) 
2. Z. Vincevica-Gaile, Biomass and Bioenergy, 125, 23-33 (2019)

3. R. Vanags Engineering for rural development, 14, 151-154 (2015)

4. W. Epper, A method of dewatering slurry, Patent GB 2083804 (Kloeckner Humboldt Deutz AG, Berlin, 1980)

5. M. M. Khachan, S. K. Bhatia, Geotextiles and Geomembranes, 45:4, 280-293 (2017)

6. Jahan I. and others. Geotextiles and Geomembranes, 46:6, 759-769 (2018)

7. F. S. Sivoney, Processing and Applications. 2, 499-530 (2020)

8. E. A Kremcheev, D. O .Nagornov, D. A. Kremcheeva, Lecture Notes in Earth System Sciences. 14, 233-256 (2020) 